DOI: https://doi.org/10.18524/2519-2523.2021.16.245740

УДК 94(477)(092)"1863/1919"

\title{
COSSACK IDEA IN ACTIVITIES OF LEADER OF THE UKRAINIAN NATIONAL MOVEMENT IVAN LUTSENKO AT THE BEGINNING OF THE XX CENTURY
}

\section{Oleksandr Muzychko}

DSc (History), Associate Professor Odesa I. I. Mechnikov National University

2, Dvoryanska Str., Odesa, 65082, Ukraine

ORCID: https:// orcid.org / 00000002-8019-2254

E-mail: sandro06@ukr.net

Citation: Muzychko, O. (2021)

Cossack idea in activities of leader of the Ukrainian national movement Ivan Lutsenko at the beginning of the $\mathrm{XX}$ century. Chornomors ' $k a$ mynuvshyna, vol. 16, pp. 65-73.

Submitted: 27.09 .2021

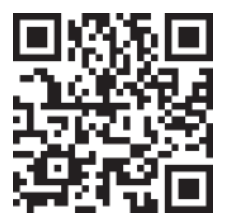

\section{Annotation}

The purpose of this article is to study the activities of Ivan Mitrofanovich Lutsenko (1863-1919) about his activities, which were aimed at popularizing the history of the Ukrainian Cossacks, the struggle for the spread of the Cossack worldview and spiritual values. I seek to deepen the study of this issue, based on previous research. The corresponding image of I. Lutsenko was reflected in the first essays-memoirs about him, the authors of which were his friends. G. Zlenko, T. Vintskovsky, $V$. Lobodaev and others wrote about I. Lutsenko as an adherent of the Cossack idea. I. Lutsenko was born in Poltava region in a family that probably had Cossack roots. In 1908, the first Cossack text by I. Lutsenko was published in the Kyiv newspaper Rada, which had not yet been taken into account by his biographers, including us. The Odessa doctor's note was devoted to the issue of P. Polubotko's treasures, which was relevant in Ukraine in the early twentieth century and then in the 1990s. The thesis about the purpose of these treasures caused doubts in I. Lutsenko, but instead he denied the opinion of D. Yavornytsky that this story is a fabrication. The apogee of the realization of these ideas precisely because of the idea of the revival of the Cossack ethos fell on the period of the Great War and the Ukrainian Revolution of 1917-1921. Many sources and memoirs reflect the contribution of I. Lutsenko during the Ukrainian revolution in the formation of detachments of free Cossacks. I. Lutsenko zealously undertook to implement the decision of the General Cossack Council on the organization of free Cossacks, especially in the regions that still "breathed" the Cossack history and traditions: Katerynoslav, Poltava,

Kherson. I. Lutsenko founded and headed the section of free Cossacks at the Odesa Ukrainian Military Council. I. Lutsenko's efforts aimed at forming the neo-Cossack idea and movement were also embodied in his writing of a number of articles on relevant topics, which were published in the Odesa editions of 1917-1918. The basis of the conceptual vision of the doctor of the Ukrainian Cossacks was antiquity and longevity, confidence that historical traditions are the foundation of modernity. He traces the origins of the Cossacks to the times of Russia, the prince's wife and the viche tradition. I. Lutsenko portrayed the social system of the Zaporizhzhy Sich in absolutely ideal tones as the embodiment of the socialist and democratic ideals that humanity dreams of. I. Lutsenko's belief in the success of the revival of the Cossacks was based on his belief in the organic nature of this idea for the Ukrainian people and its immortality. I. Lutsenko considered the hope of external support instead of belief in the strength of his own people to be a tragic historical mistake of Ukrainians. Thus, we can conclude that in general I. Lutsenko's activity was the development of populist traditions of perception of the Cossacks, but in the extreme conditions of the revolution he was one of the few people in the south of Ukraine who modernized this tradition, laid the foundation for the future state vision of the Cossack phenomenon.

Keywords: Southern Ukraine, Odesa, military, Cossacks, Cossacks study. 


\section{КОЗАЦЬКА ІДЕЯ У ДІЯЛЬНОСТІ ПРОВІДНИКА УКРАЇНСЬКОГО НАЦІОНАЛЬНОГО РУХУ ІВАНА ЛУЦЕНКА НА ПОЧАТКУ ХХ СТ.}

\section{Олександр Музичко}

Доктор історичних наук, доцент Одеський національний університет імені I. I. Мечникова вул. Дворянська, 2, м. Одеса, 65082, Україна

ORCID: https:// orcid.org / 00000002-8019-2254

E-mail: sandro06@ukr.net

Цитування: Музичко О. Козацька ідея у діяльності провідника українського національного руху Івана Луценка на початку XX ст. Чорноморська минувшина: записки Відділу історії козацтва на півдні України: зб. наук. пр. / за. ред. В. А. Смолія. Одеса: ФОП Бондаренко М.О., 2021. Вип. 16. С. 65-73.

Отримано: 27.09.2021 p.

\section{Анотація}

Метою иієї статті є дослідження діяльності одного з лідерів українського національного руху в Одесі Івана Митрофановича Луиенка (1863-1919), щуо була спрямована на відродження українських козаџьких традичій в історичних умовах початку XX ст., передусім y процесі Украӥнської револючії. І. Луценко послідовно прагнув сформувати загони вільного козацтва й у важких умовах зовнішніх та внутрішніх загроз $i$ дещо досяг $y$ иьому напрямі. Цінним є теоретичний публіцистичний доробок I. Луиенка присвячений осмисленню феномену історії украӥнського козаџтва у порівняльному контексті.

Ключові слова: південь України, Одеса, військові, козацтво, козакознавство.

У багатій на події та явища історії Одеси на особливу увагу заслуговують діячі українського національного руху, що у дуже непростих умовах прагнули включити місцеве суспільство у контекст загальної української культури та ментальності. Власне,

південь України 3 його козацькою складовою був потужною живильною силою для представників інших частин України. На початку XX ст., після “комарівського" періоду українського національного руху в Одесі (діяльність видатного літературознавця М. Комарова в Одесі у 1880-х - 1890-х рр.), на провідне місце вийшли такі молодші діячі, як С. Шелухин, I. Липа, І. Луценко. Діяльність цих осіб була особливо відчутною у громадському полі Одеси, поширюючись 3 неї як з епіцентру набагато далі. Багатогранна активність цих націєтворців вже неодноразово відзначалась у літературі. На часі заглиблення в окремі аспекти, увиразнення базових принципів світогляду цих непересічних особистостей.

Метою цієї статті є дослідження діяльності Івана Митрофановича Луценка (1863-1919) у напрямку популяризації історії українського козацтва, боротьби за поширення козацького світогляду та духовних цінностей, так як він їх розумів. Прагнемо поглибити вивчення цього питання, що вже було намічено нашими колегами та нами у попередніх публікаціях. Відповідний образ І. Луценка був відображений у перших нарисах-спогадах про нього його соратників в еміграції (див. про це нижче), але до серйозних біографічних праць так і не дійшло.

Тривалий час за часів комуністичного режиму не було можливості належно досліджувати життєвий шлях І. Луценка. Але одна 3 перших згадок у тогочасній історіографії про I. Луценка мимо волі авторів (один 3 яких сам був учасником червонокозацьких формувань, що, можливо, і зумовило згадку) включала його саме у козацький контекст [5, с. 70]. У період відродження української історіографії в умовах становлення незалежної України переважав лікарський контекст біографіки I. Луценка. Першим виразно, починаючи 3 назви статті, значення козацької ідеї у житті провідника наголосив один із найпомітніших одеських українських краєзнавців Г. Зленко [7]. В історіографії перших десятиліть ХХІ ст. цей аспект суттєво увиразнився. Згадки про I. Луценка як про активіста неокозацького руху $\epsilon$ неодмінним компонентом його життєписів. В цьому плані найбільшим є внесок одеського історика Т. Вінцковського та кропивницького історика В. Лободаєва [2-3; 27; 10, с. 151]. 
Історичні джерела вивчення теми є різноманітними. Тексти І. Луценка найбільш безпосередньо відображають його думки щодо козацтва, його прагнення до популяризації козацького досвіду, поширення його на сучасність. Хоча i, безумовно, вкрай суб'єктивні та часто такі, що важко вдаються до верифікації, $\epsilon$ мемуарні джерела, що найцінніші закарбованим у них образом I. Луценка серед сучасників. Менше, допоміжне, значення для нашої теми мали актові матеріали, що суголосні з текстами І. Луценка. Найширше ці дані наведені на шпальтах тогочасної української періодичної преси: "Рада", "Рідний курінь", "Наше село", "Вільне життя" та ін. Менше значення має російськомовна преса, хоча навіть ії «криве дзеркало» $€$ іноді цінним з точки зору вивчення стереотипів.

I. Луценко народився на Полтавщині у родині, що, ймовірно, мала козацькі коріння. Проте, ані точних відомостей про це, ані якихось автобіографічних згадок, що могли б пролити світло на вплив цього ймовірного факту для розвитку світогляду І. Луценка, на жаль, бракує. Період навчання на фах лікаря у столиці Російської імперії навряд чи сприяв захопленню козацькою тематикою. Дані про початковий період життєдіяльності лікаря в Одесі наприкінці 1890-х - до 1905 р. не містять інформації про “козацький слід”. Але дедалі глибша інтеграція I. Луценка до українського національного руху, в Одесі, знаної козакознавчими традиціями та населенням козацького походження, накладена на загальноукраїнську тенденцію «воскресіння козацьких традицій» як неодмінної складової українства як явища, закономірно призводили до увиразнення питомої ваги козацької тематики в діяльності діяча. Найбільше це відбилось в активній діяльності I. Луценка у передвоєнне п'ятиріччя у сокольському та січовому русі, зв'язках з соколами та січовиками Галичини. Ці рухи були перейняті плеканням козацьких традицій, відродженням неокозацького поведінкового типу та ономастики. Видання "Січі” та “Сокола”, “Вісті з Запорожа” І. Луценко поширював серед своїх одеських прибічниць, вчительок.

У 1908 р. у київській газеті “Рада" був оприлюднений перший дотичний до козакознавства текст I. Луценка, що ще не був врахований його біографами, зокрема, й нами [1, с. 302-307]. Замітка одеського лікаря була присвячена актуальному в Україні на початку XX ст., а потім і у 1990-ті роки питанню про скарби П. Полуботка, які, як вважала частина обивателів та вчених, він передав у Лондонський банк та заповів на користь майбутній «воскреслій Україні». Саме теза про призначення цих скарбів викликала сумнів у І. Луценка, але натомість він заперечив і думку Д. Яворницького про те, що ця історія є вигадкою. На противагу катеринославському історику, І. Луценко наводив переказ, який він отримав від своєї родички про те, що, мовляв, у 1860-х рр. про ці скарби розповідав якись землемір Полуботок з Полтавщини. Але цей переказ міг свідчити лише про побутування легенди, яку використовували у своїх інтересах певні особи. Напевно, відчуваючи це, наприкінці статті I. Луценко зробив висновок, що метафорізував поняття “спадщина Полуботка": "Гетьман Полуботко і справді зоставив і завіщав своїм нащадкам не тільки гроші, але й інший скарб щиру любов до своєї нещасної України. Коли скарби його й пропали, то друга його спадщина збереглась, ми всі його прямі наслідники до неї. Ми можемо ії одержати цілком і од нас тільки залежить взять ії і показать себе достойними його спадкоємцями” [20].

Апогей реалізації цих ідей саме через ідею відродження козацького етносу припав на період Великої війни та Української революції 1917-1921 рр., генеза та увесь перебіг якої був закономірним результатом попередніх націєтворчих зусиль, зокрема, й I. Луценка. І. Луценко свідомо змінив зовнішній вигляд, збрив бороду і залишивши вуса. Сучасник наводить слова I. Луценка 3 цього приводу, які він казав з усмішкою на початку Першої світової війни: “- А що? Хіба не козак? Поки не одягнув на себе уніформи, то й не відчував, що в моїх жилах тече козацька кров. А може таки дійсно прийдеться скоро козакувати. Адже війна скінчиться, якщо не революцією, то такими реформами, після яких і українська справа піде горою” [9, с. 47-57].

У багатьох джерелах та мемуарах відображений внесок І. Луценка у період Української революції у формування загонів вільного козацтва. Описи діяльності І. Луценка, навіть коли його не розглядали у козацькому контексті, разюче нагадують традиційні описи діяльності козацьких ватажків класичного козацького періоду [4, с. 178]. Не вважаємо це випадковістю. 
31 травня 1917 р. на зборах Одеської Української Військової Ради за головування I. Луценка було прийнято розроблений ним статут нової організації військового товариства “Одеський український військовий кіш” [28, арк. 102-103; 1, с. 219-222]. Таку назву отримало об'єднання усіх українських військових Одеської Військової Округи, Чорноморського флоту і Румунського фронту. Товариство мало культурні та політичні цілі (українізація, національнотериторіальна автономія). До товариства мали можливість долучатися і ідейно близькі не-українці. Члени Виконавчого комітету мали обирати серед себе двох товаришів голови, двох писарів та одного скарбника.

Найяскравіше образ І. Луценка як відроджувача традицій українського козацтва описав отаман Вільного Козацтва України, ад'ютант гетьмана П. Скоропадського, а у міжвоєнний період один з лідерів козацького руху І. Полтавець-Остряниця. Його спогад був присвячений Всеукраїнському з’їзду вільного козацтва у Чигирині за участі 200 делегатів від 60 тисяч вільних козаків Київщини, Чернігівщини, Полтавщини, Катеринославщини, Херсонщини, Дону та Кубані.

I. Полтавець-Остряниця наголошував на величності моменту: "По всіх шляхах, які збігалися до Чигирина, надходили козаки з усіх кінців великої Козацької Землі. Молодецькі пісні та музика, зблизька та здалека, долітали до мого вуха. Два 3 половиною століття, спавший, оповитий жидовою, Чигирин, ожив та рясно вкрився знову козацькими жупанами, прокинувшись від сну до нового національного життя Козацької Нації. Далеко за північ чувся гомін та пісні все наново надходивших козаків". На святі були присутні гості від донських та кубанських козаків. Роль І. Луценка у події він виокремив особливо: "Перед ними розвівався Отаманський бунчук та Запорозький малиновий прапор. 3 дзвіниці собору заграли дзвони. Тихо стало по козацьким рядам. Двері собору розчинилися й духовенство вийшло на паперть. Почався молебінь. По закінчеию, знову заграли дзврни і коли їх перезвін затих, вдруге вдарили довбиші в литаври. Це був знак того, що рада почалась. Нарешті литаври замовкли і на поміст піднялись три старі запорозьці Луценко, Модест Левицький і В. Левицький, батько кооперації. Вони тримали Отаманський бунчук, прапор і пірнач. Ставши серед помосту, почав старий Луценко промову. Виразно й гучно лунав його старечий голос так, що в кожному кінці майдану можна було розібрати окреме його, слово. В короткій, натхнеиій козацьким духом промові, намалював він виразно й містецько минуле й сучасне Запорозької Землі і слова його покривались нераз гучним “слава!”. Нарешті сказав він: “Отже зі йшлися ми тут, аби обрати собі Отамана!” і назвав моє імя. Я невспів опамьятатись, як був піднесений сильними руками в гору і опинився раптом на помості. Мене вкрили прапорами і гучне слава стелилось по вели кому майдану та всій околиці" [22]. На цьому з'їзді I. Луценко був обраний членом Генеральної козацької ради зі званням генерал-хорунжий [26, с. 968].

I. Луценко завзято взявся реалізовувати рішення Генеральної козацької ради про організацію осередків вільного козацтва, особливо у регіонах, які ще «дихали» козацькою історією та традиціями: Катеринославщині, Полтавщині, Херсонщині [10, с. 152]. Козацький дух опанував заходи, що відбулися в Одесі в умовах проголошення Третього Універсалу УЦР. Українська одеська військова газета з промовистою назвою "Рідний курінь" піднесено описала військовий парад: "В горі гордо майорять блакитно-жовті прапори. Недалеко грає музика - то вояки поспішають на свято, щоб тут, прилюдно поклястися життям за кращу долю України... Сотня за сотнею проходить і займає своє місце. Біля пам'ятника Катерині II розміщується славний 1-й Гайдамацький курінь. Починається парад... “Здорові пани козаки” - вітає генерал. “Здоров був пан генерал!” - 3 любов’ю, довір'ям та щирістю несеться в повітрі. А над усім ллються дивні мелодії “Вже воскресла Україна”, та “Марсельєзи”. Універсал читається окремо, кожній частині. Уважно, з напруженням, ловлячи кожне слово слухають козаки, моряки, та громадяни... Згадалося минуле нашого народу, згадалась його доля, розвій i, занепад... А на площі, в осередку, вкрита ряднами й брезентами стояла вона, виновниця політичного занепаду українців - Катерина II. Мов каячись і криючись від того, що колись зробила ..." [23]. 
3 цього приводу соратник І. Луценка А. Стрижевський згадував: «Чи треба казати, що ні один крок, ні одна справа не обходилася без І. Луценка і коли на парад почали рушати лави козаків, ми побачили його з першою частиною в лікарській шинелі верхи на коневі» [25, с. 72].

Тоді ж І. Луценко заснував та очолив секцію вільного козацтва при Одеській Українській військовій Раді. Інструкторські курси при секції виконували місію гартування, перетворення 3 малоросів українців, зокрема, шляхом посилань на козацьку спадщину. Невдовзі іï найменували "Організаційним відділом Генеральної козацької ради 3 формування Українського вільного козацького запорозького війська". У грудні 1917 р. на Білоцерківському з’їзді за участю I. Луценка було прийнято рішення надати такого вигляду вільному козацтву: “Запоріжське військо повинно бути фаховим, на взірець звичайного європейського регулярного війська, козаки повинні перебувати в ньому певний, ухвалений законами республіки, строк і вся старшина в ньому, як то було в запорожському війську під час походу, повинна бути призначеною, наказною. В січовому ж війську, згідно інструкції і як то було і в запорожському війську під час перебування на січі, старшина виборна і лише затверджується висчими начальниками" [12]. Організатор вільного козацтва у Херсонської губернії Ф. Мелешко наголошував на тому, що процес самоорганізації базувався на "статуті д-ра Луценка" [21, с. 36].

Військовий міністр УНР О. Жуковський хоч і ставився до I. Луценка без пієтету (“людина без всякого чуття”) (напевно, малась на увазі тактовність, що, справді у революційні часи, як і кунктаторство, часто тільки шкодить справі, що яскраво продемонструвала як раз більшість УЦР та Гетьманату), але водночас характеризував одесита як “старого, щирого патріота, упертого, рухливого, що добивався своєї мети до останнього” [6, с. 120].

Проте людина, яка була винесена соціальною хвилею Української революції 3 призначенням очолити козацький рух, Гетьман Української держави П. Скоропадський оцінював І. Луценка загалом негативно: “Луценко показался мне идеалистом, желавшем в наше время возродить полностью старое казачество и всю Украину перестроить на казачий лад. Он был каким-то фанатиком, ненавидевшим все русское, хотя это не помешало ему дослужиться в России, будучи военным врачем, до чина надворного советника. В денежном отношении честный, но недалекий, чрезвычайно честолюбивый, хотевший во чтобы то ни стало играть первую скрипку. Судьба потом надолго свела его со мною, и я убедился, что не ошибся в своей первоначальной оценке" [24, с. 100]. Підгрунтя цієї оцінки є цілком зрозумілим, якщо врахувати малоросійський світогляд гетьмана, адепти якого і зараз, на жаль, широко представлені в Україні i, закономірно, творять новий культ “найталановитішого політика» та «втрачений шанс для України".

Перебуваючи у своєрідному політичному шпагаті між Українською Україною та Україною як частини “возрожденной России”, П. Скоропадський сприймав І. Луценка як загрозу порушення хиткого i, як виявилося, безперспективного балансу. Існували й особисті мотиви: П. Скоропадський цілком міг знати, що саме І. Луценко був однією $з$ кандидатур на гетьмана України, але відмовився. Напевно ж, не погоджуючись на роль німецької маріонетки, яку прийняв малоросійський за світоглядом колишній ад’ютант останнього російського імператора. При тому I. Луценко не заперечував сам принцип гетьманської влади, що, вочевидь, цілком вкладалося в його уявлення про необхідність плекання та відродження козацьких традицій. Більше того, згаданий О. Жуковський атестував I. Луценка як “помішаного на ідеї відбудування на Україні Гетьмана і Гетьманської влади”. Втім, 3 історичного боку на явище гетьманства I. Луценко дивився досить скептично, вважаючи, що окрім Б. Хмельницького, П. Дорошенка та I. Мазепи усі інші гетьмани цілком заслужили гнівну оцінку Т. Шевченка: "Раби, підніжки, грязь Москви, Варшавське сміття ваші пави, Ясновельможнії гетьмани" [13].

Зусилля I. Луценка, спрямовані на формування неокозацької ідеї та руху, втілилися також у написанні ним низки статей на відповідну тематику, що були надруковані в одеських виданнях 1917-1918 рр. Основою концептуального бачення лікарем українського козацтва була задавненість та тяглість, впевненість у тому, що історичні традиції $є$ фундаментом 
сучасності [15]. Витоки козацтва він виводив з часів Русі, князівської дружини та вічової традиції. У дусі народницької традиції історії він уявляв роль князя та дружини як найманців народу, але які з часом не виконали свою функцію і залишили народні маси напризволяще перед численними загарбниками. Але потім народ сам створив собі військо - козаків [18]. Соціальний лад Запорозької Січі І. Луценко зображував в абсолютно ідеальних тонах, як втілення соціалістичних та демократичних ідеалів, про які мріє людство [19].

Українських козаків I. Луценко протиставляв російським, донським козакам, бо останні не намагалися змінити російські порядки, були відірвані від решти російського народу. В якості конкретного прикладу I. Луценко наводив практику обрання в козаків вождів: “в часи козаччини на Україні, козаки, обираючи собі ватажків-отаманів, гетьманів - ні скільки не цікавились, якої вони крови чи кости, а дивились лише на їх здібності і прихильність та щирість до народної справи". Протилежна ситуація склалась у Московії, де царя наділяли священними ознаками і він мав бути передусім “справжнім”, тобто богообраним, не таким як народ [17].

Але за усього пієтету та ідеалізації козацтва не можна твердити, що І. Луценко пропонував вдатися до такої собі історичної реконструкції, перенести козацтво у сучасність у вигляді простого аналогічного “зліпку”. Його бачення вільного козацтва було цілком прагматичним та модерним, як прояв самоорганізації суспільства, самооборони. Дуже показово, що І. Луценко як інтелігент розумів, що у XX ст. зброя вирішує далеко не все і тому закликав вільнокозачі осередки стати водночас центрами поширення освіти, що стануть базою для подальшого облаштування мирного життя: “Але організуючі силу для охорони порядку і оборони добутих прав, вільне козацтво повинно пам'ятати, що для того потрібна же одна тільки збройна сила, що для цього ще більш потрібні сила свідомості і освіти, потрібно також задоволення повсякденних турбот по потребі діла, і не тільки для себе, а й для тих, що оточують нас. Через це вільно-козачі громади і всі наші організації повинні дбати як про найширшу освіту не тільки серед нас, українців, але й серед інших народів, що живуть поруч 3 нами, повинні дбати про якнайбільше задоволення всіх найперших і найпекучіших людських потреб, приймати як найдіяльнішу участь в громадському житті, аби плекати ті ідеали, ті гадки суспільного життя, що утворили наші славні предки на Запоріжжі, бо тільки коли ми матимемо постійно на оці іх гадки, іх приклад, освічений пролитою ними кров'ю, коли ми всі наші думки, кожний свій рух, кожну свою роботу спрямуємо на той шлях постійного, невпинного поступу, тоді залізна, братовбивча зброя стане зайвою, нова зброя, зброя слова, зігрітою гарячою любов'ю до брата буде творити нове щасливе, ясне життя, якого всі ми так прагнемо, і тоді ми зможемо непотрібні більш мечі перекувати на рала й інші корисні речі, потрібні для культурного життя" [19]. Показово, що проводячи порівняльні аналогії, він уподібнював колишню козацьку старшину (тобто еліту Гетьманщини) 3 сучасною йому інтелігенцією, а не з буржуазією чи військовими, вважаючи, що між народом та інтелігенцією слід подолати розбіжності [14].

Bipa I. Луценка в успіх відродження козацтва спиралася на його віру в органічність цієї ідеї для українського народу та їі невмирущість: “гасла демократизму, соціального устрою, любові до правди, волі, світла, рідного краю, які виплекані нашим народом в його стародавнім козацтві і особливо на Запоріжжі, повинні лягти в основу будови нашої сучасної держави. Вони пережили довгі часи рабства і зараз живі в душі народу. В ідеалах сучасного громадянства нема нічого такого, чого б не було, принаймні в початкових формах, в ідеалах нашого давнього козацтва. I будуючи устрій нашої нової держави на тих стародавніх підвалинах, ми збудуємо його на міцному грунті, заложеному в душі народній. В суспільному життю ті гасла дадуть здорові і своєрідні основи для політичного, економічного і морального виховання народу. 3 військового боку вони дадуть змогу утворити дісціпліновану, кріпку армію, так потрібну для нашої молодої держави” [12].

Трагічною історичною помилкою українців І. Луценко вважав сподівання на зовнішню підтримку, замість віри у сили власного народу. Цю тезу він ілюстрував на прикладах невдач Б. Хмельницького, П. Дорошенка, І. Сірка [16]. 
Отже, українцям в історії часто бракувало осіб, які б поєднували відданість Україні $з$ загальним високим рівнем теоретичної та практичної підготовки. І. Луценко належав до числа тих провідників, що у складних умовах спромігся поєднати риси практика та теоретика козацького руху. Його публіцистична спадщина і зараз виглядає актуальною і може бути використана у патріотичному вихованні та популяризації козацтва. Мілітарність багатьох своїх заяв та дій він поєднував 3 пацифізмом, але не безглуздим, обеззброюючим та таким що веде до поразки, а продуманим, у стилі відомої латинської мудрості: “хочеш миру, будь готовим до війни". Козацька ідея I. Луценка спиралась на глибокі традиції українського народу, які він втілював і новітнім творцем яких він був. Ця ідея випромінювала оптимізмом, хоча i, як показала реальність, не завжди виправданим. Таких як І. Луценко було небагато i виявилося замало і для перемоги Української революції, і для повноцінного відродження козацтва. Таким чином, діяльність I. Луценка була розвитком народницьких традицій сприйняття козацтва, але в екстремальних умовах революції він на півдні України був одним із тих нечисленних осіб, які модернізували цю традицію, заклали основу майбутнього державницького бачення феномену козацтва.

\section{Джерела та література:}

1. Вінцковський Т., Музичко О. Іван Луценко (1863-1919): український націєтворець. Київ : Гамазин, 2013. 352 с.

2. Вінцковський Т. С. 3 історії одеської газети «Рідний Курінь». Чорноморська минувшина : зап. Від. історії козацтва на Півдні України Н.-д. ін-ту козацтва Ін-ту історії України НАН України : зб. наук. пр. Одеса, 2006. Вип. 1. С. 85-90.

3. Вінцковський Т. С. І. Луценко про вільно-козацьку організацію. Украйнське козацтво y вітчизняній та загальноєвропейській історії : Міжнар. наук. конф. (Одеса, 3-4 черв. 2005) : тези доп. Одеса, 2005. С. 61-62.

4. Гришко Г. 1917 рік в Одесі. Розбудова наџіï. 1930. Ч. 7-8 (лип.-серп.). С. 178-187.

5. Дубинский И., Шевчук Х. Червонное казачество. Киев: Политиздат Украины, 1977. $220 \mathrm{c}$.

6. Жуковський О. Вспомини часів епохи Великої Східньої Революції початка 1917-19 pр. (Із окопів до Тюрми). Записка книжечка, 1919 рік / упоряд.: П. Гай-Нижник. Київ : Авторитет, 2018. $274 \mathrm{c}$.

7. Зленко Г.Д. Він жив відродженням козацтва. Чорноморські новини. 1997. 23 квіт. (№ 32).

8. Зоць-Кравченко М. Зауваження до історії Українського Козацтва. Казачий вестник. 1944. 16 квіт. (№ 8). С. 2.

9. Кедровський В. Обриси минулого (Деякі останні діячі-українофіли напередодні революції 1917 р.). Нью-Йорк-Джерсі-Сіті : Свобода, 1966. 134 с.

10. Лободаєв В. Революційна стихія. Вільнокозацький рух в Україні 1917-1918 рр. Київ : Темпора, 2010. 672 с.

11. Луценко I. 250 літ назад. Вільне життя. 1918. 7 верес.

12. Луценко I. Вільно-козачий рух на Вкраіні і його організація. Вільне жстття. 1918. 12 трав.

13. Луценко І. Гетьман і гетьманська влада. Наме село. 1918. № 7.

14. Луценко І. Гетьман Іван Мазепа. Наше село. 1918. № 8-9.

15. Луценко І. Де-що з старовини. Наше село. 1918. № 18.

16. Луценко І. Історична помилка. Вільне життя. 1918. 4 верес.

17. Луценко I. Москвичи й царизм. Вільне життя. 1918. 17 лип.

18. Луценко І. Наші державні змагання в минулому. Наше село. 1918. № 16.

19. Луценко І. Про вільне козацтво. Рідний курінь. 1917. 30 жовт.

20.Луценко І. Ще про Полуботкові скарби (Лист до редакції). Рада. 1908. 19 січ. (№ 16).

21. Мелешко Ф. Українське вільне козацтво в Глодосах. Украйнське козацтво. 1974. Ч. 2. C. $36-38$. 
22. Полтавець-Остряниця І. Свято в Чигрині. Казачий вестник. 1943. 15 квіт. (№ 8).

23. Рідний курінь. 1917. № 14-15.

24. Скоропадський П. Спогади. Київ ; Філадельфія, 1995. 493 с.

25. Стрижевський А. І. Світлої пам'яті Івана Митрофановича Луценка [републ. спогадів 1922 року] / упоряд., авт. передм., вступ. ст. та комент. О. Музичко. Одеса, 2011. 100 с.

26. Український національно-визвольний рух, березень-листопад 1917 року. Київ : Видво імені Олени Теліги, 2003. 1024 с.

27.Вінцковський Т., Джумига Є., Мисечко А. Українські мілітарні формування в Одесі в добу Центральної Ради (березень 1917 - квітень 1918 рр.) : наук. нариси. Одеса : Фенікс, 2010. 154 с.

28.Центральний державний архів вищих органів влади та управління. Ф. 1705. Оп. 1. Спр. 7.

\section{References:}

1. Vintskovskyi, T. \& Muzychko O. (2013) Ivan Lutsenko (1863-1919): ukrayinskii natsiietvorets. Kyiv: Gamazin. [in Ukrainian].

2. Vintskovskyi, T.S. (2006) Z istorii odeskoi gazety «Ridnyi Kurin». Chornomorska mynuvshyna, issue 1, pp. 85-90. [in Ukrainian].

3. Vinckovskij, T.S. (2005) I. Lutsenko pro vilno-kozatsku organizatsiiu. In: Odessa I. I. Mechnikov National University, Ukrainske kozatstvo u vitchiznianii ta zagalnoievropeiskii istorii: proceedings of the International Conference. Odesa, Ukraine, 3-5 June 2005. Odesa: ONU. [in Ukrainian].

4. Gryshko, G. (1930) 1917 rik v Odesi. Rozbudova natsii, pt. 7-8 (July-August), pp. 178-187. [in Ukrainian].

5. Dubinskii, I. \& Shevchuk, H. (1977) Chervonnoe kazachestvo. Kiev: Politizdat Ukrainy. [in Russian].

6. Zhukovskii, O. (2018) Vspominy chasiv epokhi Velikoi Skhidnoi Revolyutsii pochatka 191719 rr. (Iz okopiv do Tiurmi). Zapiska knizhechka. 1919 rik. Kyiv: Avtoritet. [in Ukrainian].

7. Zlenko, G.D. (1997) Vin zhyv vidrodzhenniam kozatstva. Chornomorski novyny, 23 Apr. [in Ukrainian].

8. Zoc-Kravchenko, M. (1944) Zauvazhennia do istorii Ukrainskoho Kozatstva. Kazachii vestnik, 16 Apr. [in Ukrainian].

9. Kedrovskii, V. (1966) Obrysy mynuloho (Deiaki ostanni diiachi-ukrainofili naperedodni revolyutsii 1917 r.). New-York-Dzhersi-Siti: Svoboda. [in Ukrainian].

10. Lobodaiev, V. (2010) Revolyutsiina stihiia. Vilnokozatskii ruh v Ukraini 1917-1918 rr. Kyiv: Tempora. [in Ukrainian].

11. Lutsenko, I. (1918) 250 lit nazad. Vilne zhyttia, 7 Sept. [in Ukrainian].

12. Lutsenko, I. (1918) Vilno-kozachii ruh na Vkraini i yoho organizatsiia. Vilne zhyttia, 12 May. [in Ukrainian].

13. Lutsenko, I. (1918) Getman i getmanska vlada. Nashe selo, no. 7. [in Ukrainian].

14. Lutsenko, I. (1918) Getman Ivan Mazepa. Nashe selo, no. 8-9. [in Ukrainian].

15. Lutsenko, I. (1918) De-shcho z starovyny. Nashe selo, no. 18. [in Ukrainian].

16. Lutsenko, I. (1918) Istorychna pomylka. Vilne zhyttia, 4 Sept. [in Ukrainian].

17. Lutsenko, I. (1918) Moskvichi i tsaryzm. Vilne zhyttia, 17 July. [in Ukrainian].

18. Lutsenko, I. (1918) Nashi derzhavni zmagannia v mynulomu. Nashe selo, no. 16. [in Ukrainian].

19. Lutsenko, I. (1917) Pro vilne kozatstvo. Ridnyi kurin, 30 Oct. [in Ukrainian].

20. Lutsenko, I. (1908) Shche pro Polubotkovi skarby (Lyst do redaktsii). Rada. 19 Jan. [in Ukrainian].

21. Meleshko, F. (1974) Ukrainske vilne kozatstvo v Glodosah. Ukrainske kozatstvo, pt. 2, pp. 36-38. [in Ukrainian].

22. Poltavets-Ostrianytsia, I. (1943) Sviato v Chyhrini. Kazachij vestnik, 15 Apr. [in Ukrainian].

23. Ridnyj kuryn (1917), no. 14-15. [in Ukrainian].

24. Skoropadskii, P. (1995) Spogady. Kyiv; Filadelphia. [in Ukrainian]. 
25. Stryzhevskii, A.I. (2011) Svitloi pam'iati Ivana Mitrofanovycha Lutsenka [republ. spogadiv 1922 roku] / uporiad., avtor peredmovy, vstup. st. ta koment. O. Muzychko. Odesa. [in Ukrainian].

26. Ukrayinskii natsionalno-vizvolnyi ruh. Berezen - lystopad 1917 roku (2003). Kyiv: Vydavnytstvo imeni Oleny Teligy. [in Ukrainian].

27. Vintskovskii, T., Dzhumygha, Ye. \& Mysechko A. (2010) Ukrainski militarni formuvannia v Odesi v dobu Tsentralnoi Rady (berezen 1917 - kviten 1918 rr.): nauk. narysy /. Odesa: Feniks. [in Ukrainian].

28. Tsentralnyi derzhavnyi arkhiv vyshchykh organiv vlady ta upravlinnia. Funf 1705, inventory 1, dossier 7. [in Ukrainian]. 